\title{
The Distributed Archives Model: A Strategy for Sharing Authority with Partners to Document Communities
}

\author{
By Martin T. Olliff and Elizabeth Dill
}

ABSTRACT: Institutional archives with community documentation missions face problems of limited resources and community resistance in developing collections. Inspired by field experience and archival literature, the authors propose one possible solution that can be a stand-alone project or an adjunct to traditional collection development. Their distributed archives model envisions one-on-one partnerships between institutional archives and community partners to share authority over appraisal and selection while leaving custody of community collections with their creators. Institutional partners provide leadership, mentoring, and support, while community partners appraise, select, process, arrange, and describe. This article describes the distributed archives model, examines its advantages and disadvantages, and discusses it in relationship with an increased awareness of social justice concerns in archives, postcustodialism, and shared authority over appraisal between community collection creators and archivists.

While the archival profession has become increasingly sophisticated and has made enormous strides in making historical materials more accessible through new technologies and descriptive standards, it is important that it not forget the smaller, nonprofessional repositories that are also stewards of important archival collections. A more inclusive approach will help to ensure that the full range of the nation's documentary heritage is preserved and accessible. ${ }^{1}$

\section{Introduction}

Archives that serve institutions like colleges, universities, and historical societies frequently develop and acquire collections from their local communities; however, even those with a strong community collecting mission encounter problems. First, constrained resources in the archives mean community and institutional collections compete for development attention, staff time, and shelf space. Second, because some community members may be reluctant to entrust their historical materials to institutional archives, their collections are potentially lost to future researchers. Some solutions to these two problems lead to a third problem concerning how archivists conceive of their profession. Tension exists between, on the one hand, traditional selection and appraisal practices that center archivists' professional knowledge and, on the other hand, calls for shared authority, archival social justice, and noncustodialism that urge archivists to involve community members more deeply in appraisal and disposition decisions regarding their own historical materials. 
This article presents the distributed archives model as one potential solution to all three problems. The distributed archives model envisions multiple one-on-one partnerships between institutional archives and community partners. It relies on institutional archivists recognizing that because selection and appraisal decisions are acts of political power, they should thoroughly empower community holders of historical materials to make decisions concerning their own collections. In this model, archivists' selection and appraisal duties change from making decisions with donor input to advising community partners who make final selection decisions themselves. The model also anticipates that institutional partners will provide information, training, and support to community partners. For their part, community partners are expected to preserve, secure, arrange, and describe their own historical materials and then share those descriptions with the institutional partner so that they can promote the collections to researchers. ${ }^{2}$

The goal of the distributed archives model is to identify, preserve, and make available community collections that might otherwise remain unknown and to overcome community reluctance to work with institutional archives. Furthermore, it is designed for small institutional repositories that have little support or funding for outreach. Preserving and making accessible historical materials are important because the archival record, though not the sole prolegomenon of history, is a significant one. Yet, the archival record is incomplete. While institutional archivists take seriously their duty to provide access to their collections, even when professionally staffed and well organized, institutional repositories contain silences in the form of unprocessed, underprocessed, obscured, or hidden collections. ${ }^{3}$ Similarly, a community's history exists in its historical materials, but if institutional archives have silences and hidden collections, the community's historical materials are frequently unknown beyond their holders and at risk of being unused by researchers or even lost. Whether communities identify themselves by shared geography, race, gender, sexual orientation, ethnicity, occupation, or other characteristics, the loss of their documentation comes at a terrible price. For, as Michelle Caswell, Marika Cifor, and Mario Ramirez explain, to be absent from the archives is to be "symbolically annihilated" from the historical record. ${ }^{4}$

Local communities are not the only ones that suffer when their collections are missing from the archives; so do the larger societies of which they are a part, the histories of which remain incomplete without them. Archivists are very aware of this, and, in service to the historical record writ large, institutional archives have helped document communities through custodial and noncustodial community documentation projects. ${ }^{5}$ As beneficial as these projects are, sustaining them is difficult in the face of shifting institutional mandates and without significant ongoing funding. What follows is not a case study; instead, this article discusses the field experience and archival literature that influenced the distributed archives model, describes the model as the authors envision it, and then explains how the model serves participating institutional and community partners as well as the archival profession itself. Though still speculative and only partially tested, the distributed archives model offers one way for small institutional archives to more thoroughly and equitably document the communities they serve. 


\section{Background of the Distributed Archives Model}

The distributed archives model is informed by the authors' experience at the Wiregrass Archives at Troy University Dothan Campus where they developed community collections in the face of physical isolation from other professionally managed archives, constricted resources, and good-natured but stubborn reluctance of potential donors. A branch of Troy University headquartered in Troy, Alabama, Troy University Dothan Campus serves fewer than a thousand primarily nontraditional students on a nonresidential campus. The City of Dothan (population 68,000) provides medical, commercial, and cultural services to almost 500,000 residents of southeast Alabama, southwest Georgia, and north Florida. Although Dothan has a number of entities and individuals who collect not only their own records but also historical materials from the community, the closest professionally staffed archives are in Thomasville, Georgia (93 miles away); Tallahassee, Florida (104 miles); and Montgomery, Alabama (107 miles). The archives at Tuskegee University, Auburn University, and Columbus State University (Georgia) are all also about 100 miles north of Dothan.

The Wiregrass Archives opened in 2002 as a joint project of the campus's library and history department. It has three missions: to collect campus historical records, to collect community history (envisioned as a geographical community), and to coordinate information among similar organizations. For the first dozen years of its existence, it successfully developed collections among local institutions and prominent individuals. However, even after three moves and a quadrupling of shelf space, its staff still feel the pinch of insufficient resources to collect broadly and aggressively. In addition to lacking space to expand its physical collections, the Wiregrass Archives has no full-time staff members-its director works only two-thirds time in the archives and one-third in the history department—-so successfully developing community collections presents challenges.

Despite these challenges, the Wiregrass Archives developed three projects to document groups that occupy prominent places in the local society-military veterans, churches, and families-and realized from them that, while many community members kept materials of importance for documenting the Wiregrass region's history, they also kept the Wiregrass Archives at arm's length. For example, beginning in 2003, the Wiregrass Archives partnered with the Library of Congress Veterans History Project. In collecting oral histories, the Wiregrass Archives determined that many local veterans had kept documentation of their service but were not yet ready to donate it. Similarly, in 2004-2006, the Wiregrass Archives created its "Wiregrass Rural Church Documentation Project" that located, photographed, and surveyed several hundred churches in three nearby counties. A second phase of the project revealed that church members and history committees had created many small but historically important collections. Similar to Wiregrass-area military veterans, these churches were not ready to donate their records to the archives. Then, in 2016, the National Endowment for the Humanities funded the archives' Wiregrass Common Heritage Project, during which staff hosted two workshops and two community scanning days to collect digital surrogates of family 
photographs and documents. Participants were willing to donate scans to the Wiregrass Archives, but all retained their treasured originals. The grant also allowed project staff to provide archival-quality envelopes, folders, and boxes to the participants hoping they would preserve those originals. ${ }^{6}$

Archives staff discovered that some community members are unable to part with photographs, documents, and artifacts because the physical materials provoke deep memories or are signifiers of community members' identities; others are wary of either the Wiregrass Archives or Troy University; while others are uncomfortable with the idea of the archives itself. Although community members have long experience with libraries and even local history and genealogical rooms in public libraries, few have encountered institutional archives. Consequently, they have little appreciation for archives' value as well as how archives can be important assets to their communities. ${ }^{7}$ Community suspicion and mistrust of institutional archives seem to be more common than one might expect. Melanie Delva and Melissa Adams write that some community members perceive archives and their home institutions as unfriendly, self-serving, or even predatory. This was the stumbling block to cooperation between the descendants of First Nations photographic subjects and the Anglican Provincial Synod of British Columbia and Yukon archives that took substantial effort to achieve. ${ }^{8}$ Rodney G. S. Carter writes that community members sometimes actively resist institutional archives, even going as far as "to act outside the archive, to subvert it, and not to concede to having power extended over them or their records." "Andrew Flinn and Mary Stevens similarly note that trust is a factor even among community collectors who partner with, or at least understand, the mission of the institutional archives: "Experience has made [community members and community archives] cautious ... and they frequently maintain a strong sense of independence and autonomy in their decision-making and governance." ${ }^{10}$

To remedy the local community's reticence to donate their materials to the Wiregrass Archives, this article's authors looked to the third part of the archives' mission statement - coordinating information among similar institutions — and asked if achieving that goal would be possible by treating small holders of community collections as equal partners and reimagining the institutional archives' role in collection development. If so, what might that interaction look like and how might institutional archives implement it? Pondering these questions while examining the archival literature about shared authority, social justice, documentation strategies, the community archives movement, and participatory archival projects led the authors to conceive of the distributed archives model.

\section{Inspiration from the Archival Literature}

Archivists, sensitive to changing academic research needs, became interested in documenting society beyond the politically, economically, and socially powerful with the rise of social history as a legitimate historical methodology in the 1960s and 1970s. ${ }^{11}$ In his then-startling presentation at the Society of American Archivists (SAA) annual meeting in 1970, social historian Howard Zinn called upon archivists to move beyond 
gatekeeping and passive collecting from elites to actively documenting "the obscure lives of ordinary people in society." ${ }^{12}$ Others repeated and expanded his challenge. In his 1975 article "The Archival Edge," Gerald Ham called for active collecting and, though the activism of the 1970s died down by the early 1980s (in part because archivists began to accept active collecting as a professional practice), in 1986 the SAA Task Force on Goals and Priorities proposed archival changes that "could ... give the profession's mission and goals an interdisciplinary national focus . . . to move beyond planning for traditional organizational needs and to plan for the preservation of the historical record in a larger context."13

In response, archivists devised theories and practices to begin documenting society more broadly and also to try to cope with the voluminous records being generated by government and established institutions. In 1981, Gerald Ham posited that repositories are too small to acquire all necessary institutional records and that archivists should therefore develop ways to understand and manage records more broadly. He called this the "post-custodial era," which gave rise to a different way of imagining the relationship between archivists and documentary heritage. ${ }^{14}$ Larry Hackman, Joan Warnow-Blewett, Helen Samuels, and others also began to develop documentation strategies as practical solutions to the issues exposed by both archival activism and active documentation of communities. Hackman defines documentation strategy as "a plan to assure the adequate documentation of an ongoing issue, activity, function, or subject" implemented by a working group that consists of creators, archivists, records administrators, subject matter experts, and users. He also describes a detailed five-part plan for developing a documentation strategy: drafting the strategy, implementing the strategy by the group, implementing the strategy "by other parties," reporting results, and reassessing the strategy. ${ }^{15}$ Helen Samuels describes a similar four-step process for documentation strategies: "(1) choosing and defining the topic to be documented, (2) selecting the advisors ..., (3) structuring the inquiry and examining the form and substance of the available documentation, and (4) selecting and placing the documentation." Both authors agree that the working group Hackman describes is the appropriate mechanism to conduct the documentation strategy. ${ }^{16}$

Discussions led by Hackman, Warnow-Blewett, and Samuels at the 1984 SAA conference led to subsequent documentation strategy experiments in New England and the Boston area, western New York, and Milwaukee, Wisconsin. ${ }^{17}$ Early documentation strategy projects operated under administrative boards that included members from archives in physical proximity to each other-former competitors in collecting in their communities. This structure seemed designed to appease the archivists' mutual wariness as much as it did to provide a workable mechanism to document the community. While early documentation strategy projects often exhausted their partners in unwieldy planning, they did yield a refinement called "functional analysis"-that is, appraising and selecting records not only based on the structure of institutions but also on the functions that institutions perform. ${ }^{18}$

Functional analysis applies to both institutions and communities, for both have 
functions that archivists can analyze and document. Although early documentation strategies fared poorly and the endeavor was often overwhelming, documentation strategy's functional analysis, ideas of cooperation between archivists and community members, and interest in documenting a shared community found their way into the distributed archives model. ${ }^{19}$ Documentation strategies evolved in the $1990 \mathrm{~s}$, as Elizabeth Johnson notes, from a "set of procedures" to a "broader term for conscious documentary efforts conducted by archivists as an embodiment of archival activism." 20 Macroappraisal followed, most thoroughly articulated by Terry Cook and implemented by the National Archives of Canada. Macroappraisal looks beyond collecting a limited set of records toward capturing a larger universe of documentation spread across the face of society. ${ }^{21}$ Its concern about active collecting beyond traditional records and sharing authority through collaboration also informs the distributed archives model.

New voices have gone further than those of the 1970s and 1980s that called for active collecting, arguing that archivists have an affirmative duty to fill the archival silences they know exist so that neglected communities are represented in the historical records. Randall Jimerson became a foremost proponent of archival social justice with his 2007 article "Archives for All" and his 2009 book, Archives Power. He argues that archives are sites of power and that archivists should use their power of selection and appraisal to benefit society at large. Furthermore, doing so is not detrimental to the profession's operational standards. ${ }^{22}$ A decade later, Lae'1 Hughes-Watkins referred directly to Jimerson, among others, in her case study of Kent State University's Black Campus Movement Collection Development Initiative, which she states is a model for "reparative archives" to "decolonize traditional archives and [bring] historically oppressed voices in from the margins." ${ }^{23}$ However, social justice as archival activism has had its critics. Mark Greene's 2013 article-length review of Jimerson's Archives Power and the social justice turn among archivists came from inside the profession. Greene posits that social justice exceeds the limits of archivists" "professional purposes" and threatens "both our ethical standing and our power." ${ }^{24}$ These are legitimate concerns, especially as archivists suffer from austerity in the wake of the Great Recession, COVID-19 closures, and ongoing disregard for the value of archives as a public good.

More influential on the distributed archives model than either Greene's critique or Jimerson's concept of social justice is a 2008 assessment of Jimerson's "Archives for All" article. "Katie," a partially anonymous MLIS graduate student posting at the Social Justice Librarian blog, criticizes Jimerson for not going far enough. She agrees with his overall thrust, but notes that he limited his call to merely "creating more collections that document people of color" rather than expanding into other underrepresented communities. Katie calls for more discussion of "democratizing participation with archival materials" and opens a door toward strategizing about "the power imbalances when outsider archivists decide what records to collect and describe; of the ethics of removing collections from creating communities and placing them in elite institutions." 25 Katie has compellingly articulated the ethical stance of the distributed archives model in that the model's proposed one-on-one partnerships and role delineations are designed to 
rebalance power between institutional archives and "outsider archivists" (community partners), and to leave collections with the "creating communities."

The work of the community archives movement did much to address this concern about outsider archivists and the relationship between communities and institutional archives. In doing so, it, too, influences the distributed archives model. In 2009, Andrew Flinn, Mary Stevens, and Elizabeth Shepherd defined community archives in the United Kingdom as "grassroots projects and initiatives . . . dedicated to recording and preserving the memories and histories of different communities" and later as "collections of material gathered primarily by members of a given community and over whose use community members exercise some level of control." ${ }^{26}$ Community archives can range in size and complexity, and some examples include large institutions like the Japanese American National Museum and LBGTQI+ activist-operated archives like that of rukus! in the United Kingdom, as well as digital collections like the South Asian American Digital Archives and even the Centre of Memory at the Nelson Mandela Foundation. ${ }^{27}$ Rebecka Taves Sheffield's case studies of four LBGTQI+ community archives-Los Angeles's June L. Mazer Lesbian Archives and its ONE Archives, Brooklyn's Lesbian Herstory Archives, and Toronto's The ArQuives: Canada's LGBTQ2+ Archives (formerly the Canadian Lesbian and Gay Archives)—demonstrate an evolution among community archives that is important to the distributed archives model. Each emerged informally from marginalized communities that struggled continually to define community membership. Over time, each built an institution that was part of their engagement with the gay liberation movement. Each collected materials that they believed documented their community's experience and grew into more formal institutions with fractious boards of directors. When their communities became more mainstream and the leaders of these archives aged, which Sheffield calls "deradicalization," they employed different strategies to sustain their legacies. Some of these community archives allied with university archives, while others remained autonomous. ${ }^{28}$

Sheffield's case studies show that community archives tend to share three characteristics. First, they have, to a greater or lesser degree, a governing body with one or more champions who lead in identifying, preserving, and providing access to collections; second, they bring collections together into a central repository; and third, they spring from the milieu of their community often without regard to the practices of the archival profession. Community archives differ from institutional archives in their mission, organization, management of operations, and funding, but they are the same in that they take custody of collections and place them under centralized appraisal (even if various stakeholders have collaborated to create appraisal standards). The distributed archives model rejects both because they do not go far enough to solve the problem of shared authority for appraisal and responsibility for preservation. For example, while it is true that a community archives' governing board represents more of the community than does an institutional archivist, a governing board still has "insiders" who are empowered to make decisions and "outsiders" who are not. The central repository is similarly unsuitable for the distributed archives model because it requires removing collections from the creators' control. The distributed archives model does accommodate the 
third characteristic of community archives, which Sheffield calls "archival optimism" and defines as "the notion that we engage collectively in archival work because we have a sense of confidence in the future that will recognize the shared heritage that we build. . . ." Individuals and small institutions demonstrate "archival optimism" when they collect their own historical materials and the distributed archives model leverages that positive emotion.

Strikingly similar to the distributed archives model is one project that brought together existing community archives to uncover their previously hidden collections for researchers. The Historical Society of Pennsylvania's Hidden Collections Initiative for Pennsylvania Small Archival Repositories (HCI-PSAR) began in 2011 as a five-year Andrew W. Mellon Foundation-funded project to identify and enhance researcher access to small repositories around Philadelphia. The five-member project staff created a directory of 160 repositories, surveyed their collections, created what they called "summary finding aids" for 1,300 collections, and posted those to a single website. Staff also provided copies of the finding aids to the repositories along with processing plans for collections not yet ready for finding aids. Additionally, staff offered training, a website of resources for small archives, ongoing social media contact, and information on archival management and preservation practices. However, the project did not appraise, process, or digitize collections and limited its selecting activities to choosing appropriate collections to describe, leaving appraisal and accessioning to its community partners. ${ }^{30}$ Other characteristics of the HCI-PSAR are dissimilar to the distributed archives model, particularly its scale. Relying on grant funds to hire staff members to do the survey, collection assessment, description, and training work for five years erects barriers to leadership by institutional archives that have insufficient capacity to administer such grants. Additionally, the HCI-PSAR's community partners had to be established nonprofit organizations with "historically significant archival collections," though how the project determined historical significance is unclear. ${ }^{31}$ Nevertheless, the HCI-PSAR is an extraordinary and laudable postcustodial community archives project that operates at an exceptional scale and level, and some of its characteristics appear in the distributed archives model.

An even more radical departure from traditional archival practices are participatory archives projects. In 2007, Katie Shilton and Ramesh Srinivasan described projects of participatory appraisal, arrangement, and description in which archivists collected with communities rather than for them. They state that professional archivists should conduct appraisal "in collaboration with community members ... [for] the chance to assess the value of community records as the community understands them" and cite the Southeast Asian Archives at University of California Irvine and the Chicano Studies Archives at UCLA as models of this approach. ${ }^{32}$ Similarly, the University of Texas (UT) Libraries developed a participatory archives project without declaring it as such. For its Human Rights Documentation Initiative, the libraries digitized large, far-flung collections in situ, recognizing that "records creators are experts on their own records [and that] the traditional archival model disempowers record creating communities by removing the materials from their oversight and expertise." ${ }^{33}$ They also collaborated 
with their six-partner community-Free Burma Rangers, Guatemalan National Police Historical Archives, Kigali Genocide Memorial of Rwanda, Museo de la Palabra y la Imagen in El Salvador, the Texas After Violence Project, and WITNESS in the United States - to develop metadata standards that work for the libraries but are tailored to the needs of each partner. The scale and cost of the project designed to digitize and make available 10 million documents are beyond the capacity of most archives, which makes its components difficult to include in the distributed archives model. Nevertheless, the UT project demonstrates the possibilities of collaboration among equals toward distributed preservation and description that fits the distributed archives model well. ${ }^{34}$

In his case studies on two other participatory digital projects, Isto Huvila defines participatory archives as having "decentralized curation, radical user orientation, and contextualization of both records and the entire archival process." ${ }^{35}$ In the Saari Manor and Kajaani Castle projects, Huvila and his team brought together digital documents from scattered repositories and individuals to build and manage an archives "as a selfsteering system like a crowd ... [ [with] special emphasis on the collaborativeness and conversationality of archive building." ${ }^{36}$ As Huvila sees it, while a single organization hosts the digital components of the project, information managers provide technical support, while the donors, acting as a community, appraise and select collections for the corpus of the archives. In this model, the community is an "actor, and the archives will be based on a consensual community ontology . . . set within a theoretical framework based on archival science." ${ }^{37}$ Huvila also defines "radical user orientation" in participatory archives as privileging "usability and findability" of documents over preservation imperatives that limit access. He envisions a collaborative yet still centralized appraisal policy alongside a distributed network of records with digital surrogates or their links gathered into a central web portal maintained by the host institution, while the originals remain with community creators and collectors. ${ }^{38}$

Although community and participatory archives enhance the way archivists document communities, they still encounter the difficult problem of community members' reluctance to work with the institutional archives. The key to enhancing community trust, and its members' willingness to participate in preserving and making their records available, is to recognize that appraisal, selection, and custodianship are profoundly political acts that involve the exercise of power. ${ }^{39}$ In choosing what their repositories retain and exclude, archivists exercise power over the materials that record or evoke a community's memory, presence, and identification. Once archivists fully recognize that selection and appraisal establish power and authority over the historical record, armed with the imperative to document society from the bottom up, they can take the next step of sharing that authority. However, professionally educated archivists have significant investments in the standards that guide them in making appraisal decisions. For this reason, selection and appraisal standards can perform a gatekeeping function that establishes and protects the profession's intellectual authority. Fashioning authority through education in a body of knowledge, standards, and practices is, after all, one of the important purposes served by the professionalization of knowledge-based occupations throughout the twentieth century. ${ }^{40}$ However, exercising that authority only from the place of 
professional practice erects barriers between the archives and the community. Therefore, to accomplish "their cultural mission as social memory keepers" within a community, archivists should share authority equally with records creators and donors. ${ }^{41}$

\section{Description of the Distributed Archives Model}

The distributed archives model operates through individual partnerships between institutional archives that have a strong community documentation mission and resource constrained community partners who want to preserve their collections and make them accessible, but who want even more to retain authority over appraisal and custody. Although not a panacea or a "one-size-fits-all" solution to archival collection development in communities, the distributed archives model is flexible enough that it might be an attractive arrangement for both partners.

In traditional practice, institutional archivists develop collections from community members, then acquire physical custody, legal ownership, and copyright over the collections. At some point, the archivists appraise the collections according to their own institutional policies and professional best practices, accession them, preserve them, and make them accessible with modest input from the donors. The distributed archives model, however, directly addresses the issue of the political power of archival appraisal by overtly sharing authority over and responsibility for appraisal, selection, and custodianship. The model is a formalized but not rigid partnership between an institutional archives and community partners, with appraisal decisions residing with the latter. The distributed archives model also presupposes that community partners have some kind of physical repository and at least one person empowered to make decisions about the documents in their possession. Examples of potential partners in a community defined by geographical proximity, for instance, are individuals, family historians, churches, small businesses, nonprofits, social groups, civic clubs, and community service organizations. Their repositories can be as small as a single computer on which they generate born-digital records or a box containing personal papers and photographs, or it can be as large as a dedicated file room like those that church historical committees sometimes maintain.

Once an institutional archives decides to establish a distributed archives, it begins by selecting potential community partners. Although many ways to select partners exist, examples from documentation strategy approaches provide a tool: functional analysis at the community level. Because a distributed archives can begin with a single agreement between an institutional archives and a community partner, a community functional analysis can begin small and grow organically. That single partnership will cover a portion of the documentation of a community function, and the functional analysis can expand as the institutional archives develops capacity and establishes more partnerships. Furthermore, regardless of how institutional archivists define the community they want to document (e.g., geographical, topical, or organizational), many community functions, and thus partners, are obvious. For example, to begin documenting a geographical community's religious life, the institutional archives can enlist potential partners from 
churches and other religious organizations one at a time. To document family life, it can enlist individuals and family historians. To document economic life, it can enlist a single business or economic nonprofit like a regional development commission. A cursory look at the institutional archives' existing community collections will also reveal gaps and silences that provide leads to community functions and potential partners. While an institutional archives might traditionally have developed and taken custody of community collections to fill those gaps, the distributed archives model seems more likely to reduce community resistance and to reveal difficult-to-access collections.

Because a distributed archives consists of one-to-one partnerships, each one can be customized, depending on the concerns and capacities of the participants. Here, written memoranda of understanding are useful to delineate each party's role as well as its agreed-upon commitments to the partnership and to one another. Institutional archivists must be aware of their own operating rules and capacity for taking on such work before obligating themselves to avoid overcommitting themselves. A written memorandum of understanding, even if it is not an enforceable contract, has advantages over an oral agreement in that it has symbolic power that makes it difficult to ignore in the near term and more likely to encourage the signatories' successors to feel bound by it in the long term.

\section{Role of Institutional Partners in the Distributed Archives Model}

In a distributed archives partnership, the institutional partner provides training, leadership, and mentoring to community partners. Training can be in the craft of archives much like an archivist does with repository volunteers or interns. To be effective, this training should be more formalized than is usual with volunteers, because even short physical distances between the distributed archives partners make it difficult to supervise and adjust day-to-day activities. Institutional partners can provide training by hosting workshops in the basics of archival practice (a good way to recruit more community partners), conducting consultations, and making site visits. Training should address environmental conditions, disaster preparedness, processing, arrangement, description, and reference. It should also include standards as well as products, remembering that the community partners' ability to commit money, time, and effort is likely to be much lower than that of the professional staff at the institutional archives. Training in best practices for born-digital management, preservation, and access can also be provided as needed in the same way as training in managing analog collections.

Institutional partners will do well to factor in differentials in community partner capacity when considering the long-range nature of archival work. This is to say that institutional archives are ongoing enterprises with ever-expanding bodies of collections and staff who keep up with professional best practices and the archival literature. In the experience of the authors working with potential community partners, those partners are much smaller than the institutional archives, have significantly fewer resources, and have not yet acquired professional best practices and behaviors. Similarly, the vision of community partners tends to be finite and extends little beyond their own collections. 
They seek craft knowledge to identify, appraise, preserve, and provide access to their materials. While some are willing to acquire at least a basic understanding of the larger concepts of archival work, expecting community partners to view archival work in the same way institutional archivists might is counterproductive.

Institutional partners also promote a vision of the entire enterprise and how community partners fit into it; provide leadership by keeping the shared enterprise moving forward while working with each community partner; provide mentorship by recognizing that each community partner has particular strengths and weaknesses and by assisting them to enhance the former and reduce the latter.

One of the most important institutional partner responsibilities is offering resource- and consciousness-raising ideas and activities. Community partners often have some fundraising experience, but they also have insufficient capacity to find and secure grants or execute funded projects. When dealing with in-house resource providers, such as a church history committee might ask of its leadership, community partners might not be able to "sell" the idea of spending money to preserve their collections. The professional archivist, as the institutional partner, generally has the education and vision to articulate the mission of the larger project to the community partners' resource providers and to advocate for funding the archival functions required to properly maintain the community partner's historical materials. If institutional archivists are not the most politically appropriate voices to directly advocate for larger in-house appropriations or to raise outside funds, they can advise community partners in specific fund-raising activities, including writing grants, devising fund- and friend-raising campaigns, and using existing collections to create promotional resources. In addition, larger institutions often have grant-seeking offices from which the institutional partner can enlist assistance to support the overall distributed archives or any particular partnership within it.

Maintaining archival collections is expensive, whether the historical materials are analog or born digital. For analog collections that, until recently, have made up most community partners' holdings, both environmental controls and archivally sound housing might be beyond the community partner's fiscal ability. Such expense is reduced by buying at wholesale prices, but few community partners need or can afford to buy preservation supplies in bulk. Institutional partners certainly cannot donate preservation supplies, but they might be able to assist community partners in purchasing collection housing materials. Various potential approaches present themselves, such as institutional partners arranging joint purchasing efforts between community partners and suppliers, or reselling archival housing at cost. But institutional partners must think carefully before pursuing extra-institutional purchases or sales that can teem with legal, ethical, and logistical problems, and they should research such options thoroughly before including them in memoranda of understanding.

Born-digital collections pose their own problems and opportunities. Community partners might be intimidated or completely unfamiliar with ways of preserving born-digital collections. But addressing these issues during partnership negotiations and training 
can raise partners' awareness of the challenges of preserving digital records and can even clear a path for the partners to effectively manage their current records, regardless of format. Similarly, many partners who are uncomfortable with using computers may be tempted to keep every record they generate because they do not know how to prioritize the importance of digital information. Fortunately, they may also already rely on technical experts for advice and to fix computer problems. For this reason, partners may be more willing to accept archivists' records management expertise when discussing disposition of digital records than when discussing analog records.

Finally, because community partners often have limited ways to make their collections discoverable and accessible to researchers, the institutional partner should establish a central research portal to the community partners' collections. This might be as simple as a paper listing of community partners' collections or as involved as a digital database with search fields that comply with archival descriptive standards. Again, as with all archival tasks, community partners might be far less able to absorb the work of describing and providing access to their collections, so institutional partners should plan to incorporate some of these tasks into their own workflows. The establishment of a central portal, however, does not preclude direct access by researchers into community partners' collections and should not become a gatekeeping mechanism. Rather, institutional partners can assist researchers with access to distributed collections in a manner similar to the way they provide access to their own collections.

\section{Role of Community Partners in the Distributed Archives Model}

Like institutional partners, community partners also have responsibilities to their communities and organizations, their records, the project, and potential researchers. Foremost among these is that they should establish and be willing to provide ongoing support for a limited archival program for their historical materials. This idea might seem out of place, for surely community partners already have such programs. But in the authors' experience, some prospective community partners are unwilling to commit time or resources to properly process, arrange, describe, and preserve their collections, and they may end up taking advantage of the institutional partner by steering it toward establishing a repository for, rather than with, the community partner. In such a case, the institutional partner would be better served by developing that community partner's collections for traditional custody within an archival institution.

On the other hand, one should not expect a small community partner to provide perpetual resources for even the smallest archival program. Community partners' home organizations may fail. Businesses go bankrupt, churches close their doors, nonprofits stop work, and communities dissolve. As anyone who collects family papers knows, families often toss out old materials when the family historian passes away. For this reason, well-considered succession planning is the responsibility of both partners. Community partners may possibly, even likely, not consider the mechanics of long-term maintenance of their historical materials, so one of the greatest services the institutional partner can perform is to initiate serious conversations about planning for inevitable changes in the 
community partner's organizational leadership structure. Succession decisions could include transferring the community partner's collection to the institutional archives, but whatever plan emerges, it should become part of the memorandum of understanding between the two partners.

A community partner's collection caretaker often becomes its champion by virtue of their significant emotional, physical, and sometimes financial investment in collecting and preserving their organization's or community's historical materials. In an example of this, Andrea Copeland discusses two archival champions and "keepers of history" who sustained the historical records of Indianapolis's 180-year-old Bethel AME Church. Frances C. Stout served as caretaker of the church's records from the 1940s until 2004, with Olivia McGee-Lockhart succeeding her from 2004 to 2017. They assembled and maintained the materials that document Bethel's organization, its important place in the surrounding community, and even its history in the Underground Railroad and the founding of the NAACP. When Stout turned Bethel's archives over to McGee-Lockhart, she was adamant that the collection must never leave the building because she feared it would be disbursed or absorbed by an institution that would not support it as she had. But McGee-Lockhart had to reconsider this approach when it became obvious that Bethel had to move from its longtime home in downtown Indianapolis. She worked with Indiana University-Purdue University Indianapolis (IUPUI) for more than two years to ensure the collection found an appropriate home, and she led efforts to secure funds to move and digitize it. ${ }^{42}$

The example of Bethel AME Church demonstrates that sometimes archival champions can pass along their passion with their collections, and other times they cannot. When a community partner can no longer care for its collection, the institutional partner can become the repository of last resort. To postpone the severance of records and manuscript collections from their creators until those creators are comfortable parting with the materials is one of the advantages of the distributed archives model enjoyed by the institutional partner. But, until the community partner donates its materials to the institutional archives, the best path for it to follow is to implement, as much as possible, archival standards for preservation and access as well as to devise a succession plan for long-term care of the collection. The distributed archives model encourages both.

When community partners sign up for a distributed archives agreement, they should negotiate a comfortable level of cooperation with the institutional partner and be able to make a good faith effort to apply best practices in technical matters. This mirrors the institutional partner's role in providing training and mentorship. Agreeing to cooperate and accept guidance in best practices ensures that community partners do not take advantage of the institutional partner. This might mean accepting some difficult suggestions from the institutional partner. For its part, the institutional partner should recognize that inadequate resources can thwart even the most well-intentioned attempts to follow best practices and should anticipate and respond accordingly to the community partners' needs. Additionally, community partners should commit to submitting adequate descriptions to the central research portal maintained by the institutional 
partner. Furthering this and their commitments to follow the most acceptable preservation practices, the community partners should send, to the best of their ability, a representative such as a staff member or volunteer to training sponsored by the institutional partner. This is another area of negotiation. Training could encompass multiple sessions and days, thereby straining the community partners' resources and commitment to the project. For this reason, institutional partners should plan alternative and flexible delivery methods for training.

\section{Advantages of the Distributed Archives Model}

The distributed archives model offers benefits to community and institutional partners while addressing archivists' concerns about advocacy, democracy, and social justice. The most important benefit to community partners, which is also the reason to create a distributed archives, is that doing so secures the communities' histories and identities through better documentation. Other practical benefits accrue to community partners when they are better able to protect their own collections and fit them into the overall documentary record of the larger community. Community partners benefit by receiving training in best practices in preservation, description, and access, as well as a way to promote their collections to researchers who might not otherwise be aware of them. Institutional partners also benefit from the distributed archives model in several ways. First, distributed archives can help institutions fulfill their own missions to document their communities, especially when they have limited space or difficulty developing community collections. Second, institutional partners benefit because community partners do their own processing, arranging, and describing, thus helping manage possible backlogs of community documentation. Furthermore, community partners have more intimate knowledge than do institutional partners of their communities' structures and organizations, especially difficult-to-document informal structures. Such knowledge reduces the time required to research and articulate historical sketches and scope notes for community collection finding aids. The distributed archives model also makes it easier for institutional partners to identify other community functions to document. Finally, institutional archives benefit from increased community partner interaction and the development of trust. Eventually, the partners should develop a succession plan and, if the model leads to sufficient trust, community partners are more likely than before to eventually donate their collections to institutional partners.

Beyond its benefits to the partners, distributed archives offer advantages to archival advocacy, democracy, and social justice. By sharing archival practices, sensibilities, and responsibilities beyond the walls of the institutional repository, distributed archives provide more people in the community with a connection to archival work through direct participation. Such a connection and the relationships between the institutional and community partners lead to more and better advocates for the overall mission of archives and for local archival institutions. Because community partners have a stake in protecting their institutional partners, they can also become a base of support and advocacy for the institutional partner. Both partners also have a stake in maintaining historical documentation of the community that otherwise might not be identified, 
preserved, or made available, thereby preserving a much broader history than might be otherwise. This serves democracy and social justice by reducing "symbolic annihilation" of the community and its members. ${ }^{43}$ Community partners decide for themselves, with advice from the institutional partner, what aspects of their own histories are valuable to document and what historical materials fill their needs. Communities, institutions, and people who are traditionally underrepresented in archival collections stand a better chance of finding their documentation - and therefore their own history - well preserved if they or their representatives directly appraise, select, preserve, and describe their own materials.

\section{Disadvantages of the Distributed Archives Model}

On the other hand, distributed archives have potential disadvantages that archivists must consider before participating. The first is the potential of the distributed archives to validate amateurism and privilege craft over professional knowledge in the archives. In today's do-it-yourself, watch-a-YouTube-to-learn-how-to-do-something world, people frequently think they need only a little informal training to do a good job. ${ }^{44}$ Although the skills to accomplish basic archival tasks, especially preservation tasks, are not difficult to acquire, a lack of understanding of the larger archival mission can lead to the loss of records due to faulty preservation work. A related issue is the potential to lose track of collections over time because they are not under the direct control of a single, professionally managed repository. If the leader of a community partner leaves their position, they might not be replaced. If they are replaced, the new leader might have very different ideas about what is and is not appropriate to preserve, or whether preserving. historical materials is important at all. Professional archivists leave their repositories too, but their own and their successors' professional education provides a continuity of policy and best practice that makes poor decisions about deaccessioning less likely. Community partners rarely share such training and might be motivated by other considerations when assessing their existing collections. If negotiated into the memorandum of understanding, the fate of a community partner's collections in such circumstances should be more secure.

Community partners can also run into problems with acceptance of archival ethics that they have neither the professional education nor the support system to navigate. Selfinterested parties can potentially skew collecting among the community partners, just as an institutional archives might. Political pressure to accept items and collections-or to destroy them-is also a well-known problem going back as far as Sir Hilary Jenkinson's explanation of the role of the archivist in appraisal, and it has been well documented in the archival literature. ${ }^{45}$ To be successful, the distributed archives model relies on the resources of community partners, which can put irresistible pressure on them to skew their collecting to benefit the interests of their funders or home institutions. Furthermore, as much as they might understand the ethical problems with politically influenced collecting, community partners might not have sufficient cachet to resist. Preventing or countering problematic political pressure on community partners comes by establishing trust, support, and openness that provide assistance in ethical behavior to any partner 
under such pressure. The most significant ethical stumbling block in managing a distributed archives is sharing appraisal authority. Community partners retain control over their own collections and make their own appraisal decisions, which empowers them to determine the documentation that adequately preserves their own history. However, institutional partners might disagree with community partners' choices because they have very different ideas about what constitutes value. In such circumstances, the appraisal relationship between community partners and institutional partners can become fraught.

Even more difficult for the institutional partner is that appraisal lies at the core of archivists' professional identity. Like most professions, archivists define themselves in part through their specialized knowledge, at the center of which are appraisal theory and practices. That knowledge provides archivists with authority and power. That authority is not just a matter of intellectual pride; as with all knowledge professions, it makes their occupation viable. To protect their viability, archivists sometimes raise barriers to occupational entry, training, and positions. The distributed archives model, however, asks professional archivists to share their authority over selection and appraisal. Sharing authority is sharing power. A skeptic might claim that sharing appraisal authority will weaken archives as an occupation. While it might, it does so under the control of the institutional partner and in service to the greater good of society. ${ }^{46}$

\section{Conclusion: Is the Distributed Archives Model Worth the Risk?}

Despite its potential pitfalls, the distributed archives model is both achievable and worth the risk and effort required to be successful and mutually beneficial. Ultimately, it can provide research access to a community's collections as well as deliver all the benefits to underserved groups that accrue from "representational belonging," thus serving the goals of social justice. ${ }^{47}$ Because distributed archives require institutional partners to share authority over appraisal decisions concerning the community's historical recordsand even to expand the notion of what constitutes those records-it also democratizes archival practice. Consequently, the distributed archives model can serve the needs of the community and of social justice better than does current custodial practice. Expanding the reach of the archives into the community and sharing authority over the profession's most foundational theory and practice are risky, but the practical political payoff is that community partners become empowered with a greater stake in the overall archival endeavor.

This article has sought to convince institutional archives of the efficacy of building a noncustodial distributed archives as an adjunct to developing custodial collections from communities. It also has laid out a particular organizational model as well as considerations the institutional archives should bear in mind when creating a distributed archives. Some of these are practical, such as how to envision individual partnerships, the responsibilities of each partner, and the steps required to implement the model. Others are ideological, such as the politics of appraisal and of sharing authority in an 
effort to advance social justice. Whether realized on a large or small scale, the distributed archives model is just one adjunct to traditional collection development by which institutional archives can better fulfill their community-documenting missions.

\section{ABOUT THE AUTHORS}

Dr. Martin T. Olliff is the founding director of the Wiregrass Archives at Troy University Dothan Campus, where he is also a professor of history. He is the author of multiple articles on Alabama history and archival management in Alabama. He edited The Great War in the Heart of Dixie: Alabama during World War I and is the author of Getting Out of the Mud: Alabama's Good Roads Movement and Highway Administration, 1898-1928, both published by the University of Alabama Press. Olliff has served as president of the Society of Alabama Archivists, the Alabama Association of Historians, and the Alabama Historical Association.

Elizabeth Dill (MFA, MLIS), formerly director of the Troy University Dothan Campus Library, is the director of University Libraries at the University of Hartford. She has taught theater classes at the university level and presented at national and international conferences on Open Educational Resources (OER). Currently, Dill is coediting a book on OER and OER-enabled pedagogy for ACRL Publishing entitled Intersections of OER and Information Literacy. She coedited the fall 2020 special edition of the academic journal Library Trends, entitled “OER and the Academic Library." Her coauthored article, "Managing Self-Imposed Leadership Transitions during Unprecedented Challenges: Here's Your New Office! Don't Ever Come Here,” was published in the May 2021 edition of ACRL's CE'RL Nerws.

\section{NOTES}

1. Jack McCarthy, Celia Caust-Ellenbogen, and Sarah Leu, "Building an Inclusive Community of Archival Practice: The Historical Society of Pennsylvania's Hidden Collections Initiative for Pennsylvania Small Archival Repositories," Pennsylvania History: A Journal of Mid-Atlantic Studies 83, no. 1 (2016): 101, https://doi.org/10.5325/pennhistory.83.1.0097.

2. The authors are not the first to use the label "distributed archives," though by 2013 , they independently applied it to this model of collaborative preservation and access of community historical sources. The label appears in a few sources from 1999 to 2010. See Stevan Harnad, "Central vs. Distributed Archives," email, American-Scientist-Open-Access-Forum, June 28, 1999, https://www .southampton.ac.uk/ harnad/Hypermail/Amsci/0294.html; Amanda Hill and John Harrison, "Relinquishing Control: Developing the Distributed Archives Hub," New Review of Information Networking 11, no. 2 (2005): 159-70, https://doi.org/10.1080/13614570600573284; Olga Zaslavskaya, "From Dispersed to Distributed Archives: The Past and the Present of Samizdat Materials," Poetics Today 29, no. 4 (2008): 669-712, https://doi.org/10.1215/03335372-081; T-Kay Sangwand, "Building Trust and Accountability through a Distributed Archives" (Forum for Archives and Records Management Education and Research for the UK and Ireland/Network of Archival Educators and Trainers Northwestern Europe Conference, Oxford, UK, July 6, 2010).

3. Joy M. Banks, "The Foundations of Discovery: A Report on the Assessment of the Impacts of the Cataloging Hidden Collections Program, 2008-2019" (Council on Library and Information Sources, September 2019). 
4. Michelle Caswell, Marika Cifor, and Mario H. Ramirez, "To Suddenly Discover Yourself Existing': Uncovering the Impact of Community Archives," American Archivist 79, no. 1 (2016): 58-60, https://doi.org/10.17723/0360-9081.79.1.56; Christine N. Paschild, "Community Archives and the Limitations of Identity: Considering Discursive Impact on Material Needs," American Archivist 75, no. 1 (2012): 128-30, https://doi.org/10.17723/aarc.75.1.c181102171x4572h; Andrew Flinn, "Community Histories, Community Archives: Some Opportunities and Challenges," Journal of the Society of Archivists 28, no. 2 (2007): 151-76, https://doi.org/10.1080/00379810701611936; Andrew Flinn, Mary Stevens, and Elizabeth Shepherd, "Whose Memories, Whose Archives? Independent Community Archives, Autonomy and the Mainstream," Archival Science 9, nos. 1-2 (2009): 71-86, https://doi.org/10.1007/s10502-009-9105-2; Lisa Collins Shortall, “'A Permanent House for Local Archives': A Case Study of a Community's Archives in County Offaly," Archives and Records 37, no. 2 (2016): 143-56, https://doi.org/10.1080/23257962.2016.1191452.

5. Lae'1 Hughes-Watkins, "Moving toward a Reparative Archive: A Roadmap for a Holistic Approach to Disrupting Homogenous Histories in Academic Repositories and Creating Inclusive Spaces for Marginalized Voices," Journal of Contemporary Archival Studies 5, no. 1, (2018), https://elischolar .library.yale.edu/jcas/vol5/iss1/6?utm_source=elischolar.library.yale.edu\%2Fjcas\%2Fvol5\%2Fiss1 \%2F6\&utm_medium=PDF\&utm_campaign=PDFCoverPages; Josephine Wales, "Community Archives and the Archival Community" (master's thesis, Leiden University, 2014), https://openaccess.leidenuniv.nl/handle/1887/28520.

6. "Guide to the Veterans History Project Collection," Wiregrass Archives, Troy University, https:// www.troy.edu/about-us/dothan-campus/wiregrass-archives/inventories/024.html; "Guide to the Churches of Houston Co., AL Wiregrass Church Documentation Project," Wiregrass Archives, Troy University, https://www.troy.edu/about-us/dothan-campus/wiregrass-archives/inventories/078-alhouston.html; "Wiregrass Common Heritage Project," January 2016, http://spectrum.troy.edu/ WiregrassHeritage.

7. Mark A. Greene, "The Power of Archives: Archivists' Values and Value in the Postmodern Age," American Archivist 72, no. 1 (2009): 19-20, https://doi.org/10.17723/aarc.72.1.k0322x0p38v44153; Flinn, Stevens, and Shepherd, "Whose Memories, Whose Archives?," 78, 80-81.

8. Melanie Delva and Melissa Adams, "Archival Ethics and Indigenous Justice: Conflict or Coexistence?," in Engaging with Records and Archives: Histories and Theories, ed. Fiorella Foscarini, Heather MacNeil, Bonnie Mack, and Gilliam Oliver (London: Facet, 2016), 147-72.

9. Rodney G. S. Carter, "Of Things Said and Unsaid: Power, Archival Silences, and Power in Silence," Archivaria 61 (September 2006): 227.

10. Andrew Flinn and Mary Stevens, "'It Is Noh Mistri, Wi Mekin Histri.' Telling Our Own Story: Independent and Community Archives in the UK, Challenging and Subverting the Institutional," in Community Archives: The Shaping of Memory, Principles and Practice in Records Management and Archives (London: Facet, 2009), 6.

11. Peter N. Stearns, "Social History," Oxford Bibliographies, March 29, 2015, https://www.oxfordbibliographies.com/view/document/obo-9780199756384/obo-9780199756384-0131.xml; Dale C. Mayer, "The New Social History: Implications for Archivists," American Archivist 48, no. 4 (1985): 388-99, https://doi.org/10.17723/aarc.48.4.1107660916858k13.

12. Howard Zinn, "Secrecy, Archives, and the Public Interest," The Midwestern Archivist 2, no. 2 (1977): 25, https://www.jstor.org/stable/41101382.

13. Elizabeth Snowden Johnson, "Our Archives, Our Selves: Documentation Strategy and the Re-Appraisal of Professional Identity," American Archivist 71, no. 1 (2008): 191-94, https://doi .org/10.17723/aarc.71.1.81386n13w71j15v3; Gerald Ham, "The Archival Edge," American Archivist 38, no. 1 (1975): 5-13, https://doi.org/10.17723/aarc.38.1.7400r86481128424; Gerald Ham, "Planning for the Archival Profession," American Archivist 48, no. 1 (1985): 28, https://www.jstor .org/stable/40292724; Planning for the Archival Profession: A Report of the SAA Task Force on Goals and Priorities (Chicago: Society of American Archivists, 1986).

14. F. Gerald Ham, "Archival Strategies for the Post-Custodial Era," American Archivist 44, no. 3 (1981): 207-16, https://doi.org/10.17723/aarc.44.3.6228121p01m8k376; Francis X. Blouin, "History and Memory: The Problem of the Archive," PMLA 119, no. 2 (2004): 297, https://www.jstor.org /stable/w; John A. Fleckner, "F. Gerald Ham: Jeremiah to the Profession," American Archivist 77, no. 2 (2014): 378, https://doi.org/10.17723/aarc.77.2.j61g277x4rt37388. 
15. Larry Hackman and Joan Warnow-Blewett, "The Documentation Strategy Process: A Model and a Case Study," American Archivist 50, no. 1 (1987): 14, 18-29, https://doi.org/10.17723/ aarc.50.1.uxr6766121033766; Larry Hackman, "The Origins of Documentation Strategies in Context: Recollections and Reflections," American Archivist 72, no. 2 (2009): 437, https://doi. org/10.17723/aarc.72.2.g401052h82h12pm3.

16. Helen W. Samuels, "Who Controls the Past?," American Archivist 49, no. 2 (1986): 116, https:// doi.org/10.17723/aarc.49.2.t76m2130txw40746; Doris J. Malkmus, "Documentation Strategy: Mastodon or Retro-Success?," American Archivist 71, no. 2 (2008): 386, https://doi.org/10.17723/ aarc.71.2.v63t471576057107.

17. Johnson, "Our Archives, Our Selves," 195-98; Samuels, "Who Controls the Past?," 109-24; Eva Moseley, Introduction, American Archivist 50, no. 4 (1987): 468-72, https://www.jstor.org /stable/40293160; Nancy Schrock, "Images of New England: Documenting the Built Environment," American Archivist 50, no. 4 (1987): 474-98, https://doi.org/10.17723/aarc.50.4.kp38003341t68775; James O'Toole, "Things of the Spirit: Documenting Religion in New England," American Archivist 50, no. 4 (1987): 500-517, https://doi.org/10.17723/aarc.50.4.41913g1228463800; Philip Alexander and Helen Samuels, "The Roots of 128: A Hypothetical Documentation Strategy," American Archivist 50, no. 4 (1987): 518-31, https://doi.org/10.17723/aarc.50.4.v889q1182r11p36u; Samuel McReynolds, "Rural Life in New England," American Archivist 50, no. 4 (1987): 532-48, https://doi.org/10.17723/aarc.50.4.547233h430199214; T. Bassett, "Documenting Recreation and Tourism in New England," American Archivist 50, no. 4 (1987): 550-69, https://doi.org/10.17723 /aarc.50.4.m3v042g7052p575m.

18. Helen W. Samuels, Varsity Letters: Documenting Modern Colleges and Universities (Metuchen, NJ: The Society of American Archivists and The Scarecrow Press, 1992), 2-6.

19. Samuels, "Who Controls the Past?," 208; Alexander and Samuels, "The Roots of 128: A Hypothetical Documentation Strategy," 527, 529; Richard J. Cox, "A Documentation Strategy Case Study: Western New York," American Archivist 52, no. 2 (1989): 192-200, https://doi.org/10.17723 /aarc.52.2.6280321313744409; Frank Boles, "Mix Two Parts Interest to One Part Information and Appraise until Done: Understanding Contemporary Record Selection Processes," American Archivist 50, no. 3 (1987): 356-68, https://www.jstor.org/stable/40293134.

20. Johnson, "Our Archives, Our Selves," 199.

21. Johnson, "Our Archives, Our Selves," 200; Terry Cook, "What Is Past Is Prologue: A History of Archival Ideas Since 1898, and the Future Paradigm Shift," Archivaria 43 (Spring 1997): 17-63; Terry Cook, "Macroappraisal in Theory and Practice: Origins, Characteristics, and Implementation in Canada, 1950-2000," Archival Science 5, no. 2 (2005): 101-61, https://doi.org/10.1007/s10502005-9010-2.

22. Randall Jimerson, "Archives for All: Professional Responsibility and Social Justice," American Archivist 70, no. 2 (2007): 252-81, https://doi.org/10.17723/aarc.70.2.5n20760751v643m7; Randall C. Jimerson, Archives Power: Memory, Accountability, and Social Justice (Chicago: Society of American Archivists, 2009). For more recent works on the development of social justice in the archives, see David A. Wallace, "Archives and Social Justice," in Currents of Archival Thinking, 2nd ed., ed. Heather MacNeil and Terry Eastwood (Santa Barbara, CA: ABC-CLIO, 2017), 271-96; and David A. Wallace et al., eds., Archives, Recordkeeping and Social Justice, Routledge Studies in Archives (Routledge, 2020).

23. Hughes-Watkins, "Moving toward a Reparative Archive," 1-3.

24. Mark A. Greene, "A Critique of Social Justice as an Archival Imperative: What Is It We're Doing That's All That Important?," American Archivist 76, no. 2 (2013): 303, https://doi.org/10.17723/ aarc.76.2.147441214663kw43.

25. Katie, "Social Justice in The American Archivist (!)," Social Justice Librarian (blog), February 13, 2008, http://sjlibrarian.wordpress.com/2008/02/13/social-justice-in-the-american-archivist.

26. Flinn, Stevens, and Shepherd, "Whose Memories, Whose Archives?," 71, 73.

27. Paschild, "Community Archives and the Limitations of Identity"; Flinn, Stevens, and Shepherd, "Whose Memories, Whose Archives?," 74; Caswell, Cifor, and Ramirez, "To Suddenly Discover Yourself Existing"; Michelle Caswell, "SAADA and the Community-Based Archives Model: What Is a Community-Based Archives Anyway?," Tides Magazine, South Asian American Digital 
Archive (SAADA), April 18, 2012, https://www.saada.org/tides/article/20120418-704; "AR2016: The Archive," Nelson Mandela Foundation, https://www.nelsonmandela.org/content/page/ar2016the-archive.

28. Rebecka Taves Sheffield, Documenting Rebellions: A Study of Four Lesbian and Gay Archives in Queer Times (Sacramento: Litwin Books, 2019), quote from page 10; Rebecka Taves Sheffield, "The Emergence, Development and Survival of Four Lesbian and Gay Archives" (PhD diss., University of Toronto, 2015), 241-307; The ArQuives, Canada's LGBTQ2+ Archives, "2018 Annual Report," https://arquives.ca/wp-content/uploads/2019/12/TheArQuives_2018_AnnualReport.pdf.

29. Rabia Gibbs, "The Heart of the Matter: The Developmental History of African American Archives," American Archivist 75, no. 1 (2012): 195-204, https://doi.org/10.17723/aarc.75.1.n1612w0214242080; Rebecka Taves Sheffield, “Archival Optimism, or, How to Sustain a Community Archives," 3-20, in Community Archives, Community Spaces: Heritage, Memory and Identity, ed. Jeannette A. Bastian and Andrew Flinn (London: Facet Publishing, 2019), 5.

30. McCarthy et al., "Building an Inclusive Community of Archival Practice," 97-99.

31. Ibid., 98; "Hidden Collections Initiative for Pennsylvania Small Archival Repositories," Historical Society of Pennsylvania, https://hsp.org/historical-heritage-organizations-0/hidden-collectionsinitiative-for-pennsylvania-small-archival-repositories.

32. Katie Shilton and Ramesh Srinivasan, "Participatory Appraisal and Arrangement for Multicultural Archival Collections," Archivaria 63 (Spring 2007): 92-93.

33. T-Kay Sangwand, "From Custody to Collaboration: The Post-Custodial Archival Model at the University of Texas Libraries" (Stanford Prize for Innovation in Research Libraries Application, 2013), 4, https://library.stanford.edu/sites/default/files/Univ of Texas.pdf.

34. Sangwand, "From Custody to Collaboration."

35. Isto Huvila, "Participatory Archive: Towards Decentralised Curation, Radical User Orientation, and Broader Contextualisation of Records Management," Archival Science 8, no. 1 (2008): 16, https:// doi.org/10.1007/s10502-008-9071-0.

36. Ibid., 24.

37. Ibid., 26.

38. Ibid., 29.

39. Jeannette A. Bastian and Ben F. Alexander, Introduction, in Community Archives: The Shaping of Memory, Principles and Practice in Records Management and Archives (London: Facet, 2009), 8; Hans Booms, "Überlieferungsbildung: Keeping Archives as a Social and Political Activity," Archivaria 33 (Winter/Spring 1991): 25-33.

40. Richard C. Berner, Archival Theory and Practice in the United States: A Historical Analysis (Seattle: University of Washington Press, 1983); Richard J. Cox, American Archival Analysis: The Recent Development of the Archival Profession in the United States (Metuchen, NJ: Scarecrow Press, 1990); Jeannette Bastian and Elizabeth Yakel, "'Are We There Yet?' Professionalism and the Development of an Archival Core Curriculum in the United States," Journal of Education for Library and Information Science 46, no. 2 (2005): 95-114, https://doi.org/10.2307/40323864; Burton J. Bledstein, The Culture of Professionalism: The Middle Class and the Development of Higher Education in America (New York: W.W. Norton \& Company, Inc., 1976), 86-87.

41. Luciana Duranti, "The Concept of Appraisal and Archival Theory," American Archivist 57, no. 2 (1994): 328-44, quote on 341, https://doi.org/10.17723/aarc.57.2.pu548273j5j1p816; Terry Cook, "The Archive(s) Is a Foreign Country: Historians, Archivists, and the Changing Archival Landscape," American Archivist 74, no. 2 (2011): 600-632, https://doi.org/10.17723 /aarc.74.2.xm04573740262424; Michael H. Frisch, A Shared Authority: Essays on the Craft and Meaning of Oral and Public History, SUNY Series in Oral and Public History (Albany: State University of New York Press, 1990); Richard Cox and Helen Samuels, "The Archivist's First Responsibility: A Research Agenda to Improve the Identification and Retention of Records of Enduring Value," American Archivist 51, nos. 1-2 (1988): 28-42, https://doi.org/10.17723/aarc.51.1-2.gkw6742413344ug8; Barbara Lazenby Craig, "The Acts of the Appraisers: The Context, the Plan and the Record," Archivaria 34 (Summer 1992): 175-80; Cook, "What Is Past Is Prologue"; Shilton and Srinivasan, "Participatory Appraisal and Arrangement for Multicultural Archival Collections," 87-101. 
42. Sheffield, "Archival Optimism," 4-6; Martin T. Olliff, "Documenting Industry and Labor in Alabama: Can a Documentation Strategy Help?," Provenance: Journal of the Society of Georgia Archivists 16, no. 1 (1998): 55-73, https://digitalcommons.kennesaw.edu/provenance/vol16/iss1/4; Andrea Copeland, "The Bethel AME Church Archive, Partners and Participants," 15-24, in Participatory Heritage, ed. Henriette Roued-Cunliffe and Andrea Copeland (London: Facet Publishing, 2017), http://hdl.handle.net/1805/12030.

43. Caswell, Cifor, and Ramirez, "To Suddenly Discover Yourself Existing," 57.

44. "Close Enough: The Lure of Living Through Others," Hidden Brain, NPR.org, https://www .npr.org/2019/02/05/691697963/close-enough-the-lure-of-living-through-others; Michael Kardas and Ed O'Brien, "Easier Seen than Done: Merely Watching Others Perform Can Foster an Illusion of Skill Acquisition," Psychological Science 29, no. 4 (2018): 521-36, https://doi .org/10.1177\%2F0956797617740646.

45. Cook, "What Is Past Is Prologue"; Frank Boles and Julia Young, "Exploring the Black Box: The Appraisal of University Administrative Records," American Archivist 48, no. 2 (1985): 121-40, https://doi.org/10.17723/aarc.48.2.1414g624328868vw.

46. Craig, "The Acts of the Appraisers," 175.

47. Caswell, Cifor, and Ramirez, "To Suddenly Discover Yourself Existing," 67. 